\title{
Combined and uneven energy transitions: reactive decarbonization in Cuba and Venezuela
}

\author{
Donald V. Kingsbury ${ }^{1}$ \\ University of Toronto, Canada
}

\begin{abstract}
Mounting impacts of climate change have increased calls for a planetary energy transition, usually understood as the decarbonization of the global economy. All too often, however, these calls rely on technological or legislative measures, betraying an apolitical understanding of climate change and insufficient appreciation for the uneven global distribution of safety, risk, and power. Through an examination of recent events in Cuba and Venezuela, this article asks how prevailing calls for energy transitions to post-carbon futures reflect the combined and uneven present, replicating the inequalities of late carbon capitalism. By considering the 'Special Period in Times of Peace' in Cuba, as the decade following the collapse of the Soviet Union was known, and Venezuela's overlapping crises since 2014 as energy transitions, this article highlights difficulties along the path to more sustainable and just futures. It also calls to attention the intensely social, but potentially incomplete and reversible, nature of energy transitions.
\end{abstract}

Keywords: Energy transitions, Cuba, Venezuela, Special Period, extractivism, decarbonization

\section{Résumé}

Les impacts croissants du changement climatique ont accru les appels à une transition énergétique planétaire, généralement comprise comme la décarbonisation de l'économie mondiale. Trop souvent, cependant, ces appels reposent sur des mesures technologiques ou législatives, trahissant une compréhension apolitique du changement climatique et une appréciation insuffisante de la répartition mondiale inégale de la sécurité, des risques et du pouvoir politique. À travers un examen des événements récents à Cuba et au Venezuela, cet article demande comment les appels actuels aux transitions énergétiques vers un avenir post-carbone reflètent le présent combiné et inégal, reproduisant les inégalités du capitalisme carbone tardif. En considérant les transitions énergétiques résultant de la «période spéciale en temps de paix» à Cuba (la décennie qui a suivi l'effondrement de l'Union soviétique) et les crises qui se chevauchent depuis 2014 au Venezuela, cet article met en évidence les difficultés qui se produisent sur la voie de l'avenir qui sont plus durables et plus justes. Elle rappelle également la nature intensément sociale, mais potentiellement incomplète et réversible, des transitions énergétiques.

Mots clés: Transitions énergétiques, Cuba, Venezuela, Période spéciale, extractivisme, décarbonisation

\section{Resumen}

Los crecientes impactos del cambio climático han incrementado los llamados a una transición energética planetaria, normalmente entendida como una descarbonización de la economía global. Con mucha frecuencia, sin embargo, estos llamados dependen de medidas tecnológicas o legislativas, traicionando una interpretación apolítica del cambio climático y una insuficiente apreciación de una distribución desigual global de la seguridad, el riesgo y el poder. A través de una revisión de eventos recientes en Cuba y Venezuela, este artículo cuestiona cómo los reclamos predominantes por una transición energética a un futuro post-carbono, refleja un presente combinado y desigual, replicando así, la inequidad del carbono del capitalismo tardío. Al considerar el "Periodo

\footnotetext{
${ }^{1}$ Dr. Donald V. Kingsbury. Interim Director, Munk One Program https://munkschool.utoronto.ca/one/ and Lecturer, Department of Political Science, University of Toronto, Canada. Email: donald.kingsbury "at" utoronto.ca. This article has benefited greatly from on-going conversations with Gustav Cederlöf, Teresa Kramarz, and Victor Rivas. Earlier versions of the arguments presented here were presented at the Institute on Globalization and the Human Condition at McMaster University and the Department of Political Science at Guelph University. Many thanks to Carmen Bezner Kerr for her very capable research assistance. All mistakes or oversights are purely the fault of the author.
} 
Especial en Tiempos de Paz"en Cuba, cómo la década que siguió al colapso de la Unión Soviética fue conocida, y las crisis de Venezuela que se traslaparon desde 2014 como transiciones energéticas, este artículo destaca las dificultades en el camino hacia un futuro más sustentable y justo. También se presta atención a la profundamente local, pero potencialmente incompleta y reversible, naturaleza de las transiciones energéticas.

Palabras clave: transición energética, Cuba, Venezuela, Periodo Especial, extractivismo, decarbonización

\section{Adapting to climate change in the Caribbean Basin}

In April of 2018, Venezuelan President Nicolás Maduro announced the opening of Venezuela's largest water desalination plant. The president contextualized the opening of the plant, located on the Macanao peninsula on Margarita Island, in terms of climate change and human rights. In a Twitter post from August 2018, he summarized, "Climate change will leave millions of residents without water by 2030. Access to water is one of the twenty first century's biggest challenges. What are we doing to solve it? Venezuela takes action: 116 desalination plants" (Maduro 2018). State-affiliated media carried more of the message, and plans, for the desal operations. At the inauguration of the Nueva Esparta plant in 2018, national newspapers circulated Maduro's message that "We have [built] these plants in association with China, and we can export these SinoVenezuelan built plants across our national territory and throughout all of the Latin American Caribbean and Central America" (TeleSur 2018; Gobierno del Estado Bolivariano de Yaracuy 2018). The desal plant thus fits into the Maduro government's plan to provide access to potable water for all Venezuelans by 2025 while also laying the groundwork, in coordination with China, for a new national industry and new means to secure its influence - and security - throughout the region (Últimas Noticias 2018). Venezuela's construction of desalination plants as a marquee response to climate change resembles contradictory efforts elsewhere in the world that focus on adaptation rather than mitigation. The plants are, after all, financed by the sale of oil, perhaps the single commodity most responsible for our current global predicament.

Under current conditions, climate change and corresponding calls for a global energy transition - the decarbonization of the global economy - will have disastrous consequences for Venezuela's already beleaguered petroleum-reliant economy. The majority of Venezuela's electric power needs are generated via renewables; hydroelectric dams in Bolívar state. The Guri dam and power plant, one of the largest such complexes in the world, is itself vulnerable to climate change, as seen in the 2014-2016 El Niño cycle (Cawthorne 2016). By the spring of 2016 prolonged drought reduced capacity at the dam to such an extent that rolling blackouts spread throughout the country, prompting the government to shorten the official working week to two days and exacerbating already strained social and political tensions (Brodzinsky 2016).

Venezuela's electricity comes from water, but its fiscal, political, and geopolitical power sources are thoroughly determined by carbon capitalism - the global political, economic, and ecological complex in which the mobility of people, goods, and power are rooted in petroleum extraction and distribution (on the formation and vicissitudes of carbon capitalism, see; Brevini and Murdock 2017; DiMuzio 2015; Malm 2016; Mitchell 2013; Urry 2013). The desalination plants fit into a new constellation of extractive projects proposed by Maduro in response to the collapse of the oil sector since 2014, including the opening of over 10 percent of the national territory for mining by foreign firms, an extractivist response to a crisis of extractivism. Maduro's comments suggest, furthermore, that water provision could in the future supplement or replace petroleum as Venezuela's preferred diplomatic tool in the greater Caribbean basin, a welcome resource for his government after the downscaling of PetroCaribe. PetroCaribe was initially announced as a collaboration between Venezuela and Cuba in June of 2005. The program eventually expanded to include 19 states in the Caribbean basin and Central America, trading Venezuelan oil for goods and services under terms that prioritized solidarity, complementarity, and cooperation and nation-to-nation partnerships over profit and private sector interests. The program effectively ended in June of 2018 when Venezuela announced it would cease delivery to over half of the existing signatory states (Cederlöf and Kingsbury 2019).

The president's framing of climate change as a motivating factor in the infrastructure investments also called attention to other specters haunting Venezuela's government. Maduro was narrowly elected after former president Hugo Chávez died of cancer in 2013, and his tenure up to 2020 has been tumultuous, to put it mildly. Since 2013, the dangers associated with Venezuela's historic overreliance on extractive sectors have only intensified with the precipitous decline in oil prices. Ensuing social and political crises associated with 
governmental mismanagement and corruption, shortages in consumer goods, and the conflict between the increasingly authoritarian Maduro government, the opposition, and the opposition's backers in the North Atlantic have furthermore contributed to uncertainty and the shrinking of policy options.

Cuba's adaptations to climate change have been comparatively more proactive while also constrained by structural limitations. As a strategically situated island nation in a petroleum-poor region, Cuba has been subject to the geopolitics of empires since colonization in the $15^{\text {th }}$ century and then, since the twentieth century, to the petropolitics of carbon capitalism (Cederlöf and Kingsbury 2019). Cuba also occupies an acutely vulnerable position in the climate crisis. Drought, sea level rise, coral reef die-off, stronger and more prolonged hurricane seasons, erosion, and soil salination (to list only a few prominent challenges) have been constants in the twentyfirst century. With the approval of a new constitution in 2019 Cuba joined a growing number of states that ensure the right to enjoy life in a safe environment as a human right but also as the basis for sustainable and more humane development (Article 75). Article 16(f) recognizes as an aspect of foreign relations based "in the exercise of sovereignty, anti-imperialism, and internationalism, and in the pursuit of the interest of the pueblo" the obligation to "promote the protection and conservation of the environment and to confront climate change, which threatens humanity's survival." Towards this end, the article continues, these obligations must be met by "recognizing our common but differentiated responsibilities" and "the establishment of an equal and just economic order and the eradication of irrational patterns of production and consumption" (Granma 2019: 3, Artículo 16(f)). Combating climate change in Cuba is, in other words, articulated as a matter of constitutional, citizen, and human rights nested in the larger context of international solidarity.

These stated obligations are driven and constrained by necessity. In 2017, after over a decade of piecemeal responses to the climate crisis, the Council of Ministers approved a comprehensive plan under the Ministry of Science, Engineering, and the Environment (CITMA, for its initials in Spanish) to identify, prioritize, and execute progressive investments in climate change adaptation for the short (2020), medium (2030), and long term (2100) terms (Pérez Cabrera 2019). The century-long vision of this plan, Tarea Vida (Project Life), gained urgency later that year as Hurricane Irma glanced off of Cuba's northern coastline, inundating Havana's picturesque Malecón with 10-meter waves and leaving a wide swath of destruction in its wake (Stone 2018). The Cuban government requested technical and material aid from partners in the European Union (Dutch Risk Response Team 2018: 9). Adaptations prioritized under Tarea Vida have had to do with shoreline defense and relocating potentially vulnerable populations and farms, with villages deemed particularly at risk being moved immediately after the adoption of the plan, in October of 2017 (Dutch Risk Response Team 2018: 13). Among other tasks, Tarea Vida also prioritizes relocating agricultural production inland and adapting farming methods - including the replanting of its mangrove stock, which constitutes the island's first line of defense to sea level rise - to changing climactic conditions (ibid.).

Cuba's controlled economy, strong central state, and small population all facilitate rapid action in a way not replicable elsewhere. There remain, however, structural, ecological, and geopolitical limits to what it has been able to accomplish. The rationale behind Cuba's attempts at decarbonizing its electric grid, laid out in the nation's '2030 Strategy' (drafted in 2011) are as strategic and practical as they are ecological. The report frames needed changes to the energy matrix, for example, by noting how dependence on imported oil has both "drained the state economy of valuable hard currency and left it dependent on an unpredictable geopolitical environment" (Hornborg et al. 2019: 995). Despite prioritizing multiple responses to climate change, however, "in 2014, 95\% of Cuba's electricity was still generated from petroleum-based resources, both imported and domestically produced" (ibid.). The transition from fossil fuels, Hornborg et al. (2019) conclude, is hamstrung by "sociometabolic constraints" that complicate prevailing (and optimistic) approaches to decarbonization as a matter of adapting new technologies to pre-existing orders of land, labor, and capital (p. 1002). Existing infrastructures, lifestyles, and spatial organization have all locked Cuba into a carbon-intensive energy regime. Breaking with oil, even on this comparatively small scale, would necessarily entail nothing short of a complete reorganization of space and social relations. Even Cuba's authoritarian state has been unable to achieve this.

Systems - the relations between people, things, and nature - shed more light on how climate change and energy transitions will be experienced than on specific commodities, like oil. Risk, safety, lack, and excess have all been distributed rather unevenly throughout the history of carbon capitalism, largely following patterns in place since the colonial era. Latin American countries like Cuba and Venezuela are comparatively minor contributors to climate change and have, historically, been marginalized from decision-making processes in global climate and economic policy making. They have little option but to scramble to adapt to systemic shifts. 
Carbon capitalism and energy transitions, as I use the terms here, are interrelated and extend beyond commodity chains and into the state-society-nature relations with which they are entangled. Examples of prior energy transitions tend to focus, for example, on the shift from coal to oil in transport and the domestic life in North America, or earlier, on the adoption of steam power at the outset of the Industrial Revolution in England. Each of these altered the economic, social, and ecological geographies of global capitalism, thus energy transitions entail shifts in subjectivity as much as shifts in the technologies of production (Malm 2016; Mitchell 2013). Energy regimes are less organizations of caloric inputs or neutral tools for economic production than "strategies for displacing workloads and environmental burdens to other sectors of world society" (Hornborg et al. 2019: 992). They are systems for distributing the unequal risks and benefits of a self-destructive system. They define the productive and reproductive capacities of societies and establish the limits of political possibility, determining labor power, citizen mobility and mobilization, and the individual freedoms most associated with the modern era (Chakrabarty 2009). Transitions entail much more than swapping out internal combustion automobile engines for electric ones. They are, rather, upheavals of capacities, social positions, and worldviews (Verbong and Loorbach 2012: 5).

With this in mind, this article asks two main questions. The first concerns energy transitions as decarbonization and adaptation, exploring the Bolivarian Revolution in Venezuela and the 'Special Period in Times of Peace' (Período Especial en Tiempos de Paz, as the immediate post-Soviet era was known in Cuba). Rapid, deep, and enduring shifts in global, regional, and national energy systems highlight the vulnerabilities of petroleum-based development models in each country, as seen in the sudden reconfiguration in the basic operating conditions of society, from the availability of food and medicine to systems of political participation. These are cases of energy transitions conducted under the shadow of emergency and exception: reactive decarbonizations in the unequal and warming world.

In Cuba, the loss of favorable trading status with its largest group of partner states created the need to rapidly adapt its transport, electricity, and food production systems, all in the face of pressures from the United States. The particulars of the Venezuelan case are distinct, but their consequences are similar. The radical reduction in oil revenues resulted in austerity and humanitarian crisis, as in Cuba, while heightening pre-existing conflicts and instabilities. Both situations illustrate the sorts of turbulence that will accompany future decarbonization in other parts of the combined and uneven world system. They are warnings that approaches to transitions, Green New Deals, ${ }^{2}$ or sustainable development that limit themselves to established national boundaries reproduce the systemic inequalities and exclusions that produced the climate crisis in the first place.

The article's second line of inquiry considers energy transitions from a political ecology perspective. Social transformations triggered by either the sudden absence of an energy source in the case of Cuba or the crisis of an extractivist model in that of Venezuela illustrate that energy systems constitute modes of sociality. They are illustrative of what Dominic Boyer describes in terms of "energopower" in which the materiality of energy establishes political economic relations and possibilities, produces and reproduces subjects, forms relations and hierarchies, and establishes the very conditions of life itself even as they are textured and limited by larger geopolitical and ecosystemic contexts (Boyer 2014: 325). Energy transitions cannot be reduced to apolitical environmental or technical concerns. They are, for better and worse, social transitions usually executed of necessity rather than design or aspiration. Reactive decarbonization in Cuba and Venezuela illustrate the need to approach transitions in social and global terms. Anything less risks undermining the entire enterprise.

The article proceeds across four sections. In the first I discuss approaches to energy transitions as technical or legislative matters, catalytic combinations of local projects, and further reaching pursuits of social justice. The next two sections discuss the Special Period in Cuba and the post-Chávez era in Venezuela, respectively. These two instances - one concluded and influential, one developing and uncertain - illustrate farranging consequences of decarbonization, either from a loss of imported petroleum products or loss of the

\footnotetext{
2 There are prominent exceptions to nationalistic Green New Deal proposals. The idea of the Green New Deal is to couple decarbonization with programs to lessen inequality and promote job growth on a scale similar to Franklin Roosevelt's New Deal in the United States. Recent books by Naomi Klein and Kate Aronoff et al. argue forcefully that crises of climate change and neoliberalism are capable of prompting a global movement of revolutionary proportions, one that moves beyond national borders. See for example Aronoff et al. (2019), Klein (2019) and Pettifor (2019).
} 
revenues generated by exporting them. The article concludes by drawing cautious lessons from Cuba and Venezuela for thinking about energy transitions.

A caveat: I am not proposing here an exhaustively comparative political analysis of the Special Period in Cuba with the crises of post-Chávez Venezuela. The latter are still in motion, while the former will continue to have unpredictable effects into the medium- and long-term futures. As one long-time Cuba observer put it, "not perhaps since the early 1960s were existing value systems subject to as much pressure as they were during the 1990s... an entire generation came of age during these years, and it remains to be seen how the experience will act to shape the future of Cuba" (Pérez 2015: 310). Comparisons between the two experiences are currency for the arguments of the left and right in contemporary Venezuela. The right concludes the instability, power outages, and scarcity of 2017-2019 are the fault of the government, reinforcing the lesson that socialism always brings ruin (Tovar 2019). Government supporters, for their part, see in these same crises the historical opportunity to rectify, relaunch and save their Revolution (see for example the numerous opinion articles on the Special Period published on the critical chavista website aporrea.org. Maduro and his supporters, for their part, have consistently framed the difficulties they have faced in terms of a guerra económica (economic war, the epic battle of the Bolivarian Revolution against opposition sabotage and international sanctions aimed at destabilizing and overthrowing Maduro). While this article compares Venezuela and Cuba, it does so in order to ask questions of energy transitions rather than to draw definitive conclusions on their possibility or practice.

\section{On energy transitions: critical considerations}

The literature from activists, industry, policymakers, and academics on energy transitions continues to grow. At its simplest, energy transition refers to the historically recurring process by which societies at various scales replace one energy source with another. Until quite recently, transitions have been localized, piecemeal, and ponderous affairs. It was not until the Industrial Age of the 19th century, and most markedly since the 'Great Acceleration' of the Cold War era that carbon capitalism became a global force (McNeill and Engelke 2016; Smil 2016). Despite widely diverging prognoses, most approaches to decarbonizing energy transitions share a common understanding of the need to tackle contradictory challenges: to produce more energy for the planet's growing population - there will be 10 billion of us by 2050 - while cutting carbon dioxide outputs to zero and reducing concentrations of greenhouse gases in the atmosphere (Energy Transitions Commission 2016: 3; Guzmán 2013; Institute of the Americas 2015). Without the aggressive de-carbonization of the economy, they argue, any hope of meeting the goals set out by the Intergovernmental Panel on Climate Change (IPCC) to keep temperature rise to less than 2 degrees Celsius is impossible. Even this goal, and the 2017 Paris Climate Accords with which it is often associated, warn climate scientists, will be insufficient to the scale and complexity of a problem that can only be described as an act of "intergenerational injustice" (Hansen et al. 2013).

Steven Bernstein and Matthew Hoffman begin from the recognition of a lack of systemic order or capacity from which to respond to the climate crisis. Agreements like the Paris Accords, they argue, offer more pragmatic than maximalist approaches to transitions, meaning inevitably that "much of the actual work of decarbonization required will be undertaken or catalyzed by a wide array of other actors, including subnational (e.g., municipal, state/provincial) and non-state" (Bernstein and Hoffman 2018: 190). The shift:

...embodies at least the beginnings of an even more profound conceptual shift in how we understand the problem of climate change: from a legal regime conceived as a negotiated distribution of commitments to solve a collective action problem (reduce emissions) to preserve a global commons (a stable climate) to a catalytic mechanism to promote and facilitate transformative pathways to decarbonization. (ibid: 190)

Before anything as grand as a planetary energy transition can be realized, in other words, a multitude of local actions need to occur to disrupt further carbon lock-in. Indeed, due to the highly interconnected nature of planetary energy systems, "an intervention in one place can also alter the politics in others" (ibid: 195). Decarbonization is thus less an end or target than the accumulation of independent processes, example effects, and a mix of intended and unintended consequences pursued by a multiplicity of actors.

The truths of these observations cut in multiple directions, calling attention to the challenges of energy transitions. Recent reversals of climate policies at the national and subnational levels in North America such as 
the Trump administration's withdrawal of the United States from the Paris Climate Accords in 2017, or the Trudeau government in Canada's dogged attempts to expand the Trans Mountain Pipeline from Alberta to coastal British Columbia highlight the reversibility of climate legislation in liberal democracies (Al Jazeera 2019; Kestler-D'Amours 2016; Milman et al. 2017; Shear 2017; Tasker 2019). What is more, the virtuous catalysts of municipal climate change disruptions in the North Atlantic described by Bernstein and Hoffman may well mitigate climate change while further entrenching established inequalities across the North and South. In the absence of binding global regulations, the North Atlantic has been much more apt to downsize its carbon footprint by offshoring polluting industries than by replacing them with green ones (Li and Zhou 2017).

Many of the most powerful states prioritize geostrategic and economic continuity over immediate action toward decarbonization (Goldthau and Witte 2010: 3). Security analysts, military strategists, and the keepers of the global economy are already hard at work establishing contingency plans to protect themselves and their interests from the turbulence of this warming world (Bradshaw 2010; Bridge 2015; UNFCC 2014, 2016; UNGA 2018). Much of the developed world has taken the substantive approach of "accelerated investment in selective adaptation" amounting to the "creation of green and gated oases of permanent affluence on an otherwise stricken planet" (Davis 2010: 38). The result, as a 2019 United Nations document warns, is a looming "climate apartheid" that will continue to exacerbate the already uneven distribution of political, civil, social, and human rights. This transition is an extension of the established order, which amounts to so much dilly-dallying by liberal democracy in the face of climate crisis, putting itself at risk (Carrington 2019).

Outside this obstinate realpolitik, justice concerns often frame international calls for transition, but rarely is this justice transformative in nature. The resulting actions are most striking in their familiarity. Among current proposals with any sort of weight among policymakers and industry, there is a widespread acknowledgement that "those that have contributed least to global warming [are] often...the hardest hit" by its most disastrous consequences (e.g., ECLAC 2015: 2). There is also an increasing tendency to integrate decarbonization into plans for inclusive and sustainable development (e.g. IPCC 2014). However, existing plans emphasize management within minimally reformed political and economic frameworks and technological fixes as the only viable path forward. In the place of coherent collective action, energy transitions look to a combination of entrepreneurial ingenuity and technological miracles to correct for the excesses of extraction and carbon capitalism (Gudynas 2015: 73; Szeman 2019: 110). Calls for public-private partnerships, minimal-but-rational and transparent state regulation, investment in new technologies (including geoengineering), and public education campaigns to correct wasteful consumerism dominate proposed strategies for negotiating life in the Anthropocene (Generation Energy Council 2018; Stern 2007; Swyngedouw 2010). The persistence of marketbased common sense in development, sustainable or otherwise, is as much the case in Latin America as anywhere else, even before the post-neoliberal 'Pink Tide' of left-of-center governments receded (Coronil 2011; Escobar 2010; Gudynas 2015; Svampa 2017). The resiliency of the idea of the market as an unassailable standard operating procedure of global politics persists, despite the growing recognition that climate change is less a consequence of the actions of humanity writ large than a negative side effect of carbon capitalism's specific mode of industrial and post-industrial life. This is not an accident: millions if not billions of dollars have been spent by carbon capital on instrumental, discursive, material, and institutional work to maintain this status quo (Geels 2014). We are in other words midstream in a transition, one that is currently being managed by the same class of elites that produced the crises of the present (Mann and Wainwright 2018: 11).

Technological and market approaches to energy transitions assume a linear and progressive trajectory of development. Christoph Bonneuil and Jean-Baptiste Fressoz (2016) correct for this tendency, complicating the form and composition of transitions when they write that:

...there has never been an energy transition. There was not a movement from wood to coal, then from coal to oil, then from oil to nuclear. The history of energy is not one of transitions, but rather of successive additions of new sources of primary energy. (Bonneuil and Fressoz 2016: 101)

According to their analysis, talk of transition first emerged in response to the oil shocks of the 1970s. 'Transition' is in this light a euphemism for the civilization-jarring effects of a sudden shift in primary energy source, conjuring images of commodity frontiers rather than system collapse. The implied promise is that each 
transition sees a higher intensity energy source adopted, societies advance along conventionally accepted human development indices, and aggregated economic growth reaches ever greater heights. Climate change may be an immediate threat, but if properly navigated it also presents investment opportunities for future prosperity; another challenge met by the unconquerable human spirit. With the specter of green capitalism and with the spread of global consciousness on climate change (or so the sales pitch goes) a new, more efficient, post-carbon global energy mix will be cobbled together, with consumption levels at near current rates. As the following sections illustrate, the cases of Cuba during its 'Special Period' and Venezuela in its present crisis call these approaches into question.

Unlike technocratic or conservative approaches, criticisms framed in terms of justice and just transitions place the blame for climate change squarely at the feet of carbon capitalism (Huber 2015; Knuth 2015; Malm 2016; Mann and Wainwright 2018; Moore 2015). Within this literature, interventions encompass energy, environmental, and climate approaches to justice, examining how "the benefits and burdens of climate change" are distributed "from a human rights perspective", the energy life cycle's uneven expression across different groups, the degree to which citizens are able to participate in environmental governance, and the "implementation and enforcement of effectiveness or enforcement of environmental laws, regulations, and policies" (Heffron and McCauley 2018: 74). Approaches span disciplines. Economists like Lucas Chancel and Thomas Piketty have for example, linked higher rates of inequality with increased carbon dioxide emissions (Chancel and Piketty 2015). Geographers and International Relations scholars emphasize the need to

...be alert to the political economy of global environmental justice, characterized as it is by uneven power relations, conflict and often violence, and shaped as it is by a global political economy in which the interests of global elites are more often than not misaligned with the energy needs and environmental vulnerabilities of the world's poorest people. The praxis of the just transition will have to centrally address the key political economy questions of 'who wins, who loses, how and why' as they relate to the existing distribution of energy, who lives with the side effects of its sites of extraction, production, and generation, and who will bear the social costs of decarbonizing energy sources and economies. (Newell and Mulvaney 2013: 133)

Just transitions approaches examine the ways in which "the locations, landscapes, and territorializations associated with a low-carbon energy transition will generate new patterns of uneven development" (Bridge et al. 2013: 337). They are global in scope and transformative in orientation. Some, such as the Petrocultures Research Group of humanities and social science scholars highlight the need to reassess and abandon core progressive assumptions of the developmentalist worldview characteristic of North Atlantic hegemony: "the petro-fuelled progress vision imagined always more; but there will always now be less" (Petrocultures Research Group 2016: 62), a reckoning also signaled by decolonial scholars in Latin America (Escobar 2010) and the degrowth movement (Martinez Alier 2009; Rodríguez-Labajos 2019; Sandberg et al. 2019). Just transitions approaches insist that responses to climate change and the pursuit of decarbonization cannot be divorced from history. They of necessity include highly technical and technological solutions, but cannot be reduced to apolitically 'scientific' or market-driving fixes. A just transitions perspective thus approaches energy transitions as illuminating ways in which developmentalist imaginaries reproduce inequality on a global scale, unevenly distributing the harms and privileges of carbon capitalism across space and time. Most importantly, just transitions insist on the need to take corresponding, sustainable and participatory, transformative action to change these historically entrenched dynamics.

In this way we can also appreciate how, in Clark Miller and Jennifer Richter's (2014) estimation, "Energy transitions are thoroughly social affairs" (p. 77). They continue:

....at its most incremental, this may mean that new energy hardware introduced into a plant - or a new programmable thermostat introduced into the home - requires new skills to successfully operate. At the other end of the spectrum, the rise of new energy resources (or the end of old one) can give rise to massive reconfiguration of social, environmental, and technological landscapes. (ibid: 78). 
Energy transitions seen as social transformations reopen the basic operating processes of a given society for negotiation and contestation. As energy systems are entangled in processes of wealth creation and distribution, transitions reopen questions of the distribution of power and wealth, costs and benefits, safety and risk (p. 79). These redistributive openings may also trigger structural shifts in the geographical and temporal organization of society, altering behavior and subjectivity (p. 79). As energy, and control of access to energy, play a key role in defining geopolitics, change in an energy regime may also undermine existing authorities or support the rise of new ones. Finally, energy capacities not only shape what currently existing societies can do and how they see themselves, but also how they imagine themselves in the future. Energy is tied to existing rationalizations and subjugations, but so too is energy intertwined with desires, hopes, and aspirations (p. 79). Energy transitions recompose state-society-nature dynamics in ways that defy prediction.

As the sudden energy transitions in Cuba in the 1990s and Venezuela in the twenty first century illustrate, the catalytic effects of deeply interconnected and nested energy systems are also likely to trigger negative social impacts in the immediate and medium terms, which can in turn trigger further environmental harms. This was seen, for example, in intensified deforestation as Cubans sought sources of alternative fuels in the absence of oil in the early 1990s (Díaz-Briquets and Pérez-López 1995: 287). Without attention to existing supply chains and their socio-ecological contexts, catalytic and example effects of new global energy technologies may also intensify environmentally damaging industries elsewhere. This has been the case in Cuba and Venezuela's new extractive frontiers, in the expansion of mining for materials such as Lithium, necessary for 'green' technologies, or indeed, if in a more retrograde register, in the fracking and bitumen booms of the US and Canada. All of these highly disruptive 'alternatives' may seem contradictory to the needs of the present, particularly from a distance. However, policymakers' and citizens' choices are constrained by their positions in the global division of nature; embedded fossil fuel infrastructures and extractive worldviews offer paths back to the status quo ante that remain tempting for policy makers across the political spectrum.

The Cuban and Venezuelan cases also illustrate the extent to which catalyzing energy transition efforts are limited by geopolitics. Cuba may perhaps be the clearest example of a successful, or at least most complete, post-petroleum energy transition in recent memory. However, even its much-celebrated agroecological transformation faces significant internal and external political, economic, and environmental limitations (Fernández et al. 2018: 20). While the decentralization and decarbonization of its food systems are laudable, and necessary, its wider influence has been much more limited. That the United States has not rushed to replicate the Cuban model - against the full force of the powerful agribusiness lobby - should not come as much of a surprise. Even ostensibly progressive local governments have prioritized the demands of property developers over community gardeners, as seen in the fate of the South Central Farm in Los Angeles, California. First planted in 1994, the 6-hectare farm comprised 360 plots tended by 330 families - the largest urban farm in the United States. It was a project of community-building in the aftermath of the 1992 uprisings, and an important provider of food security in a poverty-dense region. It was bulldozed in 2006 in accordance with a court injunction filed by a property developer. As of 2019, the space remains undeveloped and unused (see Irazábal and Punja 2016).

Who drives and who is driven by energy transitions and geopolitics within carbon capitalism can seem familiar. But these familiar patterns raise concerns for Latin America's ability to navigate the climate crisis. Just as Cuba was forced to pursue an energy transition because of exogenous shocks - the demise of the Soviet Union - so too are other sites in Latin America considered 'blank slates' for the application of transition schemes, rather than places from which the ideas for the shared pursuit of decarbonization originate. These approaches replicate rather than replace existing inequalities, relegating responses to the climate crisis to yet another example of neocolonial South-North relations and potentially limiting their effectiveness.

\section{Cuba: the Special Period in times of peace}

The 1990s in Cuba, labelled by that government the "Special Period in times of peace", saw a massive and fundamental overhaul of a state-society-nature matrix that had been developing over the course of nearly 30 years. With the collapse of the Soviet bloc, Cuba lost a key political ally and shield against aggression from the United States. It also, just as importantly, it lost its primary source for the petroleum on which it had come to depend. The ensuing decade of reactive decarbonization entailed the creative but nonetheless forced process of finding alternatives to petroleum while also revising the state-society-nature dynamics of carbon intensive socialism. Understood as an energy transition, the Special Period prompts us to ask about the human and natural 
consequences of forced decarbonization, to ask who establishes the coordinates of transition, and, ultimately, its reversibility.

Shortly after its victory in January 1959, the Cuban Revolution was forced by the zero-sum logic of the Cold War to align itself with the Soviet bloc. Fidel Castro's initial promises that allegiance with the USSR would accelerate Cuba's exit from neocolonial dependency, monocrop agriculture, and the influence of the United States, would shortly prove unfulfilled. Trade with the Soviet bloc did not bring about the diversification of Cuba's productive base: sugar remained king. It did however accelerate the industrialization of Cuba's main cash crop and daily life. Imported petroleum was key. Sugarcane cultivation was increasingly mechanized and became progressively capital- and chemical-intensive throughout the 1970s and 1980s. Following the Soviet developmental model, electrification was also vigorously pursued as the Revolutionary government moved to deliver on promises of modernization (Cederlöf 2017: 118). The good life of a socialist middle class was promoted throughout the 1970s and into the 1980s, marked by an increased availability of CEMA-made (Council for Economic Mutual Assistance) consumer goods, many of which relied on petroleum-generated electricity from the newly expanded grid (Cederlöf 2017: 127). Socialism in Cuba was (and remains) uniquely independent and anti-imperialist, but has also been influenced by the developmentalist imaginaries of the Soviet and North Atlantic blocs. Electrification and increased access to consumer goods marked progress, even as the island remained tethered to forms of economic production that had been dominant for centuries. Rather than resulting from endogenous or organic shifts within the Cuban economy, improvements in the quality of life were dependent on economic planning, the export of sugar, and the import of oil, petrochemicals, natural gas, and capital and consumer goods. It was a carbon-intensive socialism incubated under siege conditions.

During this era, "anthropocentric and social issues, such as education, health care, economy and security ranked high on the country's priority list", while "environmental issues were of no importance" (Maal-Bared 2006: 350). Throughout the era of Soviet-Cuban trade and development, Cuba followed a Green Revolution model of carbon-intensive agriculture, utilizing "higher levels of fertilizers, mechanization, and irrigation than the USA, and certainly more than other Latin American countries" (Wright 2009: 58). Industrialized agriculture and mining polluted waterways, intensified soil salinization, degradation, and erosion, and contaminated the air. By the 1970s and 1980s the situation had deteriorated such that the United Nations Development Program provided technical and financial assistance to deal with pollution (Díaz-Briquets and Pérez-López 1995: 282).

This carbon-intensive socialism ended with the collapse of the Soviet bloc. What is more, with the disappearance of its primary source of imported consumer goods and energy resources, Cuba was suddenly vulnerable to US-imposed sanctions in a qualitative and quantitatively different way. As Louis Pérez, Jr. (2015) notes, prior to the Special Period CEMA imports amounted for over $85 \%$ of Cuban trade across all sectors, and oil imports decreased by $90 \%$ within a year of the fall of the Soviet Union. Cuba's agriculture system was also thrust into a dangerously precarious state: fertilizer production declined by $80 \%$, dairy products by half, meat by two thirds, poultry by 80\%, and pork by 70\%. All told, "between 1990 and 1993, the Cuban economy shrank by more than 40\%" (Pérez 2015: 305). The impact was severe and felt daily, as average caloric intake among the population fell by as much as 30 percent (Wright 2009: 4). Population outflows increased during the Special Period, as the government loosened emigration controls as a means to lessen sociopolitical tensions intensified by the economic crisis. The Special Period also triggered an affective shift: "the years of the Período Especial evoked signs of an apocalyptic premonition, especially in the cities...an eerie silence descended upon urban neighborhoods in the evenings as the sights and sounds of the city so much associated with gasoline and electricity ceased" (Perez 2015: 307).

Emily Morris (2014: 17) argues, "Fidel Castro's characterization of the crisis years as a 'Special Period in time of peace' was seen by outside observers as a euphemism, but within Cuba it was immediately understood as a reference to established civil-defence procedures, in case of natural disasters or US attack." Understanding the Special Period as a natural disaster offers a grim premonition of the climate crisis. Morris expands,

...the Economic Defense Exercise of 1990 - in which electricity and water supplies were cut off for short Periods, to rehearse emergency collective responses involving factories, offices, households, schools and hospitals - used methods of collective organization and multi-agency coordination similar to those of hurricane-preparedness or military-defence exercises. The same types of mobilization were evident in the early 1991 Food Programme, in which farmers and city dwellers were called upon to contribute to food production; the December 1991 Spare 
Parts Forum, on ideas for recycling machinery and substituting for imports; and the January 1992 Energy Plan, in which households, enterprises, and local authorities identified ways to cut fuel consumption. (Morris 2014: 17)

The energy transition that was the Special Period called for ingenuity, discipline, and sacrifice to navigate extreme circumstances. It forced a shift in Cuba's productive capacities, but that shift also triggered an upheaval of daily life; a transvaluation of the means by which Cubans judged progress and identity on a scale similar to the victory of the Revolution in 1959 (Pérez 2015: 310).

The Revolution disrupted the urban-rural divide, class systems, and neocolonial status that defined Cuba since independence from Spain at the end of the nineteenth century. The Special Period in turn overhauled the state-society-nature dynamics of the post-revolutionary period. Forced by circumstance to move away from the "ideological rigidity" of the preceding years and to open toward "pragmatic innovations" that included decentralization of the state's most important social welfare and economic practices; the introduction of new forms of collective ownership and decision making; limited forms of private property and legalized entrepreneurship; and organic and biodynamic agriculture based on smaller-scale and urban farms (Pérez 2015: 316; see also Cederlöf 2017: 195; Fernández, et al. 2018; Kapcia 2018). Decentralized and urban smallholder agriculture began as key survival strategies as large scale and state-owned industrial farms became less viable - "by 1998, Havana had more than 26,000 urban gardens, producing 540,000 tons of fresh fruits and vegetables" (Wright 2009: 6) - but also became a base for reimagining the place of the collective in the state-society-nature relationship (Premat 2003).

As an energy transition, however, the Cuban case poses a few troubling questions for decarbonization more generally. First and foremost, to highlight the Special Period's successes makes a virtue of necessity if it fails to register the human toll and geopolitical context of imposed transition. As Bonneuil and Fressoz (2016: 104 summarize, Cuba comprehensively overhauled its social and technological energy matrices:

...in order to save on energy, working hours in industry were reduced, domestic electricity consumption was rationed, the use of bicycles and car pools was generalized, the university system was decentralized, solar energy and biogas were developed (supplying 10 per cent of electricity). In agriculture, the cost of pesticides and chemical fertilizers, very greedy in terms of energy, led the Cubans to innovate: biological control of pests by insect predators, organic fertilizers, and urban horticulture that enabled the recycling of organic waste. Finally, food was strictly rationed.

Despite this comprehensive response, and even with the aid of a consolidated authoritarian state and established command economy model, reductions in carbon dioxide emissions during the Período Especial were only relatively modest "falling in ten years from 10 million to 6.5 million tonnes, much less than the 40 to 70 percent reduction of world emissions by 2050 called for by the IPCC that could cap global warming to a two-degree Celsius increase" (p. 104). The Cuban energy transition is the most comprehensive empirical example we have in recent years, barring perhaps the case of North Korea over the same period. Even with this in mind, the net reduction of the island's carbon footprint was minimal - a footprint that was miniscule to begin with in comparison with the United States, Europe, and China and which, thanks to the prevalence of a small set of industries on the island, relatively straight-forward.

Secondly, the Cuban energy transition is not irreversible, suggesting the need for more comprehensive sociopolitical, economic, and transnational measures to be wired into decarbonization mechanisms. We can appreciate the degree to which reactive decarbonization is particularly vulnerable to reversals. As experiments with decarbonization responded to the disappearance of Soviet oil, for example, the Castro government "went all out" to increase domestic production of petroleum, which is "of very low quality and has a very high sulphur content, thus generating a great deal of air pollution" (Díaz-Briquets and Pérez-López 1995: 287). Cuba did not transition in the name of conservation; it had to do so, and did so with the perfectly rational, understandable, and humane desire to normalize (that is, "recarbonize") the state-society-nature matrix as soon as possible.

In many ways the Special Period ended when oil returned to Cuba. Starting with the election of Hugo Chávez in Venezuela in 1998, Latin America was swept by a 'Pink Tide' of left of center presidencies. While this left turn was always characterized by more ideological and policy diversity than unity, the reintegration of 
Cuba into the regional community, and an avowed skepticism of cutthroat neoliberal economics, constituted a shared norm across national administrations (Kapcia 2008: 173). The rise of China as a significant regional actor in foreign direct investment and trade, furthermore, opened another important door for Cuba - by 2008 China's was the island's second largest trading partner, after Venezuela (Pérez 2015: 347). Finally, while continuing a stubborn policy of isolation and sanctions, the United States' focus throughout the 00's on a 'global war on terror' targeting the greater Middle East at least moderately eased pressure on the island (Pineo and Birns 2013). This pressure was further released with the diplomatic thaw between Cuba and the United States during the late years of the Obama administration (Hirschfeld Davis 2017; Roberts 2016) before the reversals of the Trump administration and the resurgence of the right throughout Latin America (Romano and Tirado 2018; TeleSur 2019).

While Cuba has not fully returned to its carbon intensive and mono-agricultural past, the end of the Special Period has meant its energy mix is no longer as green and lean as in the 1990s, when it was necessary to be so for lack of alternative energy sources. On the whole, petroleum consumption remains drastically lower than during the highpoint of trade with the Soviet Union and the Eastern Bloc (Cederlöf 2017: 20). However, an "oil for doctors" agreements with Venezuela in the early 2000s, for example, as well as other bi- and multilateral agreements like PetroCaribe has allowed Cuba to once again utilize and expand its fossil-fueled infrastructures (Cederlöf 2017: 218-221). What is more, Cuba has opened its territorial waters to foreign firms seeking to tap into the estimated 15 billion barrels located in its deep waters (Fabricant and Gustafson 2017: 442). Cuba's transition was triggered by exogenous conditions; when those conditions shifted, so too did the nature of the transition.

In Cuba the sudden absence of oil exposed seemingly unrelated systems - food production and the university sector, for example - as being wholly integrated into and dependent upon the networks of fossil fuel production and consumption. That Cuba was able to navigate the seismic shift of losing its primary energy source at all - even at the tremendous human cost of the Período Especial - is a remarkable feat. However, celebrations of the conversion of the entire island to a sustainable model have been overblown. They were necessary and difficult adaptations rather than long-term commitments. Even more concerning is the fact that decarbonization in Cuba never matched the scale of global decarbonization required to salvage actually-existing societies from ongoing climate change. This is especially the case if the transitions aim to maintain an economic model that prioritizes endless growth and (unevenly distributed) mass consumption, as is the case in many mainstream approaches. Finally, the Cuban government navigated the transition that was the Special Period while maintaining its focus on human health and welfare. While infant malnutrition rates spiked to their highest levels in decades during the Special Period, life expectancy and other welfare indicators in Cuba remained favorable in relation to many of its more developed neighbors (Pérez 2015: 308). Public health crises in other disaster zones - Haiti after the 2010 earthquake or Puerto Rico after its 2017 hurricane season, for example offer glimpses of how much worse the Special Period could have been, how disastrous the coming global transitions could be, and how unevenly their impacts may be distributed (Bonilla and LeBrón 2019; Dupuy 2010).

\section{Venezuela: transition as collapse?}

Venezuela is often considered the first PetroState. The PetroState thesis, as developed by Terry Lynn Karl (1999) and others (e.g., Ross 2012), suggests that the boom and bust cycles of petroleum markets malform institutions, encourage corruption, and sow the seeds for political and social unrest. However, while many iterations of the PetroState thesis practice a sort of methodological nationalism, focusing on domestic stakeholders, institutions, and policies, PetroStates are better understood as nodes in a transnational web of energy, power relations, and ecology than as dysfunctional islands in an otherwise prosperous free market sea. The negative effects of overreliance on commodity exports should not, however, be underemphasized. In 2018, petroleum accounted for 99\% of Venezuela's national export earnings (OPEC 2018), despite the fact that Venezuela's production declined by over half between 2015-2018 due to sanctions and deteriorating infrastructure (Monaldi 2018; Rousseau 2015; Vázquez 2015). The performance of governments across regime types have, furthermore, depended on oil production, as extractivism - an ideology linking extraction of natural resources to national development (Arsel et al. 2016; Gudynas 2015; Terán-Mantovani 2014) - has become an imperative spanning civilian, military, democratic, and now Bolivarian governments for a century. 
It follows, then, that Venezuela has never proactively pursued decarbonization, but has rather sought to increase oil and natural resource exports (Grisanti 2011; Vázquez 2015). During boom years, this has allowed the state to consolidate its control over national territory, secure the recognition of peer and more powerful states and multinational corporations, and radically transform physical and infrastructural space in pursuit of modernization (Blackmore 2017). Only very recently has it attempted to merge deep-seated extractivist worldviews and development plans with discourses of environmental sustainability. The result has been cognitively dissonant. The 2007-2013 Plan de la Patria, for example, recognizes climate change as a pressing national concern and calls for the construction of 'ecosocialism' while simultaneously aiming to cement Venezuela's role as a "global energy power" and advising that "the production and use of petroleum and energy resources ought to contribute to the preservation of the environment" (Terán-Mantovani 2014: 194).

Ambivalence has characterized Venezuela's relationship to oil from the beginning. As early as 1936, when Arturo Uslar Pietri called for planners to 'sow the oil' to make extraction productive rather than parasitical, policy and opinion makers cautioned against the destabilizing effects of the oil economy (D'Angelo 2017). The industry and the anxieties that surround it continue to define national identity and political fault lines into the twenty first century (Coronil 1997; Kingsbury 2016; Salas 2009). Oil, and extractivism more generally, must be understood not merely as elements in economic production, but rather as the foundation for state-societynature relations in Venezuela. Decarbonization in Venezuela thus extends beyond the loss of a singularly important commodity: it signals a rupture within the state itself, undermines development models, and sends shockwaves through the national imaginary.

The Venezuelan PetroState formed as a result of global and domestic pressures. The Great Depression and Second World War weakened demand for its chief agricultural exports (mostly cacao and coffee), and the post-war reconstruction and Cold War economic boom increased demand for Venezuelan oil (Mommer 2010: 87-88). Real GDP growth in Venezuela was the highest in Latin America of the era, and the military government of Marcos Pérez Jiménez (1948-1958) enjoyed tremendous material capacities during the boom. According to Coronil (1997: 187), "in the period between 1950 and 1957, ordinary oil revenue grew an average of 11.6 percent and government income an average of 13.9 percent annually, while the total value of oil exports increased 250 percent and treasury reserves 400 percent." During this period, the dictator reconstructed the country, investing in modern and monumental infrastructure as a means of securing modernization (Blackmore 2017).

After the overthrow of Pérez Jiménez in January 1958, control of the PetroState passed to the two-party system established by the Pacto de Puntofijo (Puntofijo Pact, signed by the center-right COPEI and center-left Acción Democrática, or AD). Civilian rule did not, however, fundamentally change the exclusionary or developmentalist orientation of the PetroState, as seen for example during the oil boom of the mid 1970s. Coinciding with Carlos Andrés Pérez's first term (1974-1979), the construction of La Gran Venezuela Venezuela the Great - deployed expanded revenue to underwrite a class compromise between masses and elites while continuing the infrastructural development of previous administrations (Terán-Mantovani 2014). As Kevin Neuhouser (1992) observes,

The post-1973 dominance of AD/COPEI was based on the combination of vastly increased oil revenues and increased state access to those revenues. Between 1958 and 1969, the average real price per barrel of Venezuelan oil dropped from US\$2.48 to US\$1.81. In the inter-election Period of 1969-1973, however, the price of oil increased 105 percent; government income from oil increased 105.4 percent; and total government increased 85.4 percent. Although the biggest portion of these increases came in 1973, there were significant increases in the preceding years. From 1973 to 1974, the increase was even greater - government income from oil jumped 226 percent and total government income grew by 165.1 percent. Since 1973, AD and COPEI have used these state oil revenues to address the short-term material interests of both capitalists and workers (125-126).

Oil allowed post-dictatorship administrations to balance consumption and accumulation demands. The result was a state-society-nature dynamic of state-led development funded by oil revenues. However, the political logic of this Puntofijo system also meant Venezuela's foreign debt ballooned during these years, as funds earmarked for development disappeared in capital flight and corruption (DiJohn 2009: 231-233). 
Dwindling revenues, skyrocketing debt, and the neoliberalization of the global economy reduced Venezuela's ability to fund social peace and petroleum-financed progress in the 1980s and 1990s. The era of austerity that began with Venezuela's "Black Friday" devaluation in 1983 became inescapable as oil prices foundered throughout the 1980s (Lander 1996: 50). These difficulties boiled over in the Caracazo of late February 1989, an uprising against International Monetary Fund-imposed austerity measures and government crackdown that murdered scores of Venezuelans. By 1992, a year of two attempted military coups and the impeachment of the president on corruption charges, the three decades-old exclusionary Puntofijo pact disintegrated amid freefalling social and economic conditions (Terán-Mantovani 2014: 148).

In the ensuing decade, successive administrations implemented piecemeal structural adjustment measures, including the opening of the oil sector and privatization of other public industries. As in other cases throughout the region, the results of neoliberalization in Venezuela were "ambiguous at best" (Escobar 2010: 2). Venezuelans arguably felt harder done by structural adjustment than others, as they followed decades of the oil-inspired confidence that la Gran Venezuela was on the horizon. This 'lost decade' was characterized by downward social mobility and deteriorating public services. These were also years of social and spatial fragmentation as crime rates spiked, and the fear of crime spawned a generalized securitization of daily life and distrust of public institutions, the police, and the political class (Sanjuán 2002: 88; Zubillaga 2013:111). In two decades, Venezuela plummeted from the richest country in Latin America to the one with the highest rates of per capita debt. According to the Venezuelan Ministry of Coordination and Planning (CORDIPLAN), by 1999 the country had poverty rate of 80 percent, with 39 percent in extreme poverty, and 37 percent of children suffering malnutrition. Unemployment reached 15 percent, with over half of the workforce employed in the informal sector (cited in Terán-Mantovani 2014: 152). This drastic deterioration of social, political, and economic conditions opened the door for radical outsiders like Hugo Chávez.

Chávez promised to convoke a constituent assembly and to rewrite Venezuela's constitution along 'Bolivarian' principles of sovereignty and constituent power, moves which were accomplished by 1999. The new government's diplomatic energies upon taking office centered on rejuvenating OPEC and increasing global oil prices (Lander 2007). By 2003, when the government took control of the national oil industry, the statesociety-nature complex had fully returned to the dynamics of the Petrostate. For the next ten years, despite echoing the long-held concerns about oil's unpredictability and negative side effects, the Bolivarian Revolution intensified the state's reliance on the industry. Using historically high oil prices, Chávez favored policies to reverse the poverty, inequality, and exclusions of the 1980s and 1990s for most Venezuelans while increasing investment in the country's social and civic infrastructure. All but the most recalcitrant critics of the opposition recognize that the social gains were significant (López Maya 2014). Extreme poverty was nearly eradicated, and Venezuela was certified illiteracy-free by the United Nations in 2005. Inroads were made in extending access to health care, education, safe and dignified housing, and food security for the country's poor majority through an expanding array of government-sponsored social programs, the Misiones Bolivarianas (Bolivarian Missions). The rhetoric of the government increasingly centered on the drive to build a "socialism for the twenty-first century." Chávez also asserted Venezuela's sovereignty in international and regional forums, insisting on the need for South-South solidarity and the construction of a multipolar world freed from the overbearing influence of the United States (Ellner 2007; Ellner and Tinker Salas 2006; Wilpert 2007).

On Chávez's death his successor, Nicolás Maduro, took office under conditions amounting to forced decarbonization. The collapse of oil prices that followed the great recession of 2008 deepened significantly in 2014, compounding structural problems in the Venezuelan economy, depleting state resources, further encouraging corruption, and triggering staggering rates of inflation (Cohen 2018). Economic difficulties and Maduro's failure to forge a charismatic tie to a majority of Venezuelans in the same manner as Chávez has emboldened the perennially intransigent opposition, who have used violent protests, electoral contests, and appeals for international sanctions to isolate, destabilize, and they hope, overthrow the government (Buxton 2016). What is more, the negative consequences of difficult global petroleum markets have been exacerbated by problems inside the state oil company, Petróleos de Venezuela, S.A. (PDVSA), which, after 'opening' and increased internationalization in the 1990s faltered in the 2000s due to mismanagement, lack of capital upkeep and investment, and foreign pressures (Monaldi 2018; Rousseau 2015; Vázquez 2015).

Without wanting to contribute to the generally voyeuristic tone of much media coverage of Venezuela's troubles since 2014, the human cost of this transition should not be understated. For example, the International Monetary Fund has suggested that the hyperinflation that has been mounting since 2014 could reach 
$10,000,000 \%$ in 2020 . The Maduro government at least partially acknowledged this reality when it announced fiscal measures (reconversión monetaria) in August of 2018 that, among other actions, devalued the Bolívar Fuerte (Strong Bolívar) - itself rolled out only in 2007 - and replaced it with the Bolívar Soberano (sovereign Bolívar), removing five zeros from the hyperinflated currency. Meanwhile, shortages in basic foodstuffs and medicine have been exacerbated by US-led sanctions, estimated to have contributed to the death of 40,000 people since August of 2017 (Weisbrot and Sachs 2019). By 2019 prominent analysts warned of the prospect of famine if the trending decline in food imports is not reversed (Smilde 2019).

Blackouts have also been taking place at an increasing rate. As in the case of Cuba during the Special Period, they perforate the fabric of life itself, forcing populations to revise their daily schedules, work, leisure, and reproductive labor. In both nations, blackouts add to the general anxieties of societies navigating uncertain political realities. While in Cuba they resulted from rationing as the island ran out of fuel for its diesel electric generators, in Venezuela the story is slightly more complex. Rolling blackouts were triggered throughout 2016 as three years of persistent droughts brought water levels in the El Guri dam - which produces some $60 \%$ of the national electricity supply - to historic lows. As one commentator noted, "contrary to what we might assume, in today's sustainability-minded world, the choice [to invest in hydroelectric generation] did not arise from a noble commitment to renewable energy" but rather, "to preserve as much of its oil as possible for export" (Bakke 2016). However, Venezuela has neither diversified its renewable energy sources nor properly maintained and upgraded its electricity infrastructure. As a result, when climate change intensifies unpredictable $E l$ Niño cycles, as it did in 2016, the deep shocks to existent energy systems require significant adaptation. In sum, the electricity crises of 2016 (repeated in 2018 and 2019) were political and politicized. They jolted the daily lives of Venezuelans, while heightening anxieties that already accompanied a society midstream in the competing social and political transitions of the government and opposition.

The deteriorating situation has triggered a mass migration of Venezuelans out of the country, seeking stability. The United Nations High Commissioner for Refugees estimates over 4 million - of a population of roughly 32 million - Venezuelans fled by 2019 (UNHCR 2019a,b). As opposed to previous waves of migration, the current migrants come from the popular sectors, further casting doubt on the medium- and long-term viability of the Bolivarian project under Maduro's leadership. Venezuela's ongoing energy transition much more closely resembles a collapse, as the Maduro administration has proven lacking in the political resources and conditions, let alone skill, to effectively steer the country beyond the implosion of carbon-intensive socialism for the twenty-first century.

\section{Energy transitions as uneven and reactive decarbonization}

This article has explored experiences in Cuba's 'Special Period in Times of Peace', and the collapse of Venezuela's oil industry, to ask questions about ongoing energy transitions. Energy transitions are disruptive, but not everyone experiences disruption in the same way. The warnings offered by Cuba and Venezuela's experiences are clear and striking, but they are also familiar in a global order long marked by inequality and maldevelopment. If they make for grim reading, it is because they are projections of the world as it currently exists. In the words of the Petrocultures Research Group, all too often thinking around energy futures

... tell us more about the present than they do about the future. Energy transition characterizes the global present, but the lived experience of that transition is not the same the world over and is characterized by inequalities on varying scales. ... [T] his is no apocalyptic vision. This is the energy present. (Petrocultures Research Group 2016: 63)

If transitions literatures and projects too often look to the same mechanisms that produced the current climate crisis to correct it, and if they reproduce through omission the inequalities of the present, then understanding existing transitions in the Global South can help not only produce more holistic responses to present crises, but more just ones as well.

It is thus understandable that countries facing greater challenges will continue to pursue carbon-based development strategies if they become available. A striking example of this reality can be seen in Ecuador. A member of OPEC since 1973, Ecuador's constitution of 2008 was widely celebrated as leading the charge in sustainability by endowing nature with rights and elevating ecological conservation as a core mandate of the 
country complementary to (rather than antagonistic with) human development. However, this window of environmental progressivism was closed by the time of the failure of the Yasuní-ITT supply-side decarbonization initiative in 2013. Shortly after taking office in 2007, former President Rafael Correa took on an initiative proposed by social movements since the 1990s to protect fragile ecosystems and indigenous territories in the Ecuadorian Amazon by leaving oil in the ground in exchange for compensation from the international community (Acosta et al. 2000). Over the ensuing five years less than ten percent of the requested US\$3.6 billion was pledged to the United Nations trust created for the human development projects to which the monies would be dedicated. Correa withdrew the proposed initiative in 2013 and extraction began (Kingsbury, Kramarz and Jacques 2018). After that, Ecuador's reliance on oil and mineral extraction, regardless of the environmental or human consequences, intensified (Kingsbury, Kramarz and Jacques 2018; Riofrancos 2017).

Ecuador's course of action after the failed Yasuní-ITT initiative can also be seen in Cuba and Venezuela. In each case the government responded to a crisis in one extractive-based sector of the economy and society with enhanced reliance on other extractive sectors. Where possible, both countries have also attempted to extend the lives of their respective oil economies. Cuba has increasingly relied on tourism, mining, and later, offshore drilling to fill the economic hole left by the Soviet Union. Similarly, Maduro has proposed a shift to megamining projects for gold, diamonds, and coltan - the last a necessary component for the so-called green technologies of the post-carbon economy - to take oil's place. These immediate responses to crises seek alternative revenue streams to maintain existing sociopolitical energy regimes: new inputs for established systems that maintain both countries' subordinate positions in the global division of power, labor, and nature. Arguably, they have little other choice.

The Castro regime did not pass through the difficulties of the Special Period unchanged, and nor did the patterns of daily life go unchanged for Cubans adapting to the energy transition it imposed. Even if it was eventually brought back into the Latin American community of nations without regime change and within the developmentalist imaginary of the Pink Tide, the decentralizing and decarbonizing reforms altered the shape and substance of Cuban Socialism. They did not, however, end it. The social-energy transitions of the Special Period did not entail a wholesale capitulation to the market-based rationalities of the "Washington Consensus" as seen elsewhere throughout the post-Soviet bloc. They were rather "adjustments" in the face of radically altered external conditions pursued under the guidance of "principles" forged over the course of three decades of siege by the United States. "These principles", writes Emily Morris, "included upholding national sovereignty, preserving los logros de la revolución - the gains or achievements in health, education, social equality and full employment; often referred to simply as los logros - and maintaining 'revolutionary ethics', which has involved a strong official stand against corruption and disapproval of ostentatious display" (Morris 2014: 12). Energy transitions are social affairs in which existing power relations and the organization of work, life, and future aspirations are called into question and reorganized. But so too are they guided and constrained by existing institutional frameworks and modes of sociality.

Maintaining collective spirit and refusing to sacrifice whole sectors of the population and landscape to the neoliberal rationality of the post-Soviet social and energy transition is admirable. However, Cuba's options in the course of transition remained limited by the blunt realities of its surroundings. The US embargo enforces austerity and constrains the options for a government still committed to providing for the health and welfare of the population. The extractivist model remains intact, in oil and mining, for example (Fabricant and Gustafson 2017; Marsh 2017). Dependence on Venezuela and China remains a concern, particularly considering the former's ongoing turbulence.

Similarly, the energy transition underway since 2014 in Venezuela has seen social conditions deteriorate and tensions rise, but it has yet to culminate in the regime change sought by the opposition and its backers in Washington. Much less have the present troubles enabled the construction of the "communal state" pursued by social movements at the grassroots. The ongoing energy transition has undermined president Maduro's authority in the eyes of current and former Chavistas, and precarious access to basic necessities from electricity to medications has triggered a reorganization of daily life in communities and workplaces, particularly as growing numbers of Venezuelans leave the country. Disappearing oil revenues have reduced the caloric intake, health, and security of Venezuelans as the extractive state model on which development has relied for nearly a century fumbles to reinvent itself in the face of geopolitical and market-imposed decarbonization (Hodal 2019; Human Rights Watch 2019; Kurmanaev 2019; UNHCR 2019b). 
This type of reactive decarbonization, for better and for worse, attempts to limit the energy transitions' negative social consequences. Moves to decentralize food production and to collectivize distribution in both Cuba and Venezuela through urban agriculture, for example, are necessary responses to systemic shocks. They have the added virtue of mobilizing people to directly participate in responding to the challenges imposed by transitions. They are also, however, intensely local in nature, and at present supplement rather than replace the internationalized, industrial, and carbon-intensive agricultural networks in which both countries are entangled.

Secondly, and necessarily, energy transitions call into question the extractive model on which carbon capitalism depends. Extractivisms are not reducible to the carbon capitalist energy mix, but the latter cannot exist without the former. Both rely on and reproduce the same set of human-nature relations and, what is more, reproduce the structural dependency of exporting nations on the global core. Responding to the crises of decarbonization with new waves of extraction thus does little to shift social relations in more politically and socially sustainable directions on either local or global levels. For example, the scramble to exploit the world's largest Lithium deposits in the so-called "Lithium Triangle" at the borders of Argentina, Bolivia, and Chile has triggered a speculative "white gold rush" for a central commodity in the renewable energy supply chain, expanding mining frontiers even deeper into fragile ecosystems (The Economist 2017).

\section{Conclusion}

Returning to the broad questions set out in the Introduction: how do the experiences of Cuba and Venezuela inform current approaches to energy transitions? How do these questions lend themselves to political ecology perspectives, on the energopower and energopolitics of late carbon capitalism? Tentatively, and with an eye toward future research and action, the first question lends itself to growing calls for a global green new deal. Failure to approach energy transitions globally, in an inclusive and egalitarian fashion, leaves little other likelihood than the sort of crash-landing reactive decarbonizations of Cuba and Venezuela. However, at the same time, the continuation of top-down, paternalistic, and otherwise exclusionary developmentalist approaches to transitions, global or otherwise, are prone to reversibility, and offer little incentive for uncoerced 'buy-in' from the Global South.

On the energopolitical aspects of reactive decarbonization, the Cuban and Venezuelan cases illustrate in stark detail how transitions are never purely technical matters. Transitions not only replace dirty commodities for clean ones in the pre-existing energy matrices. They are rather shifts in the state-society-nature dynamic, putting into question the distribution of risks and benefits of existing and future political ecologies, of identity, and of the nature of development.

Reactive decarbonizations in Cuba and Venezuela illustrate the consequences of unfolding and uneven energy transitions. While the sort of scaling up and catalyzing effects of local responses to climate change are of vital importance and perhaps inevitable, and while academics, activists, and policymakers should do all in their power to amplify them, one should also avoid making a virtue of necessity. Piecemeal transitions or Green New Deals confined to the existing national boundaries and geopolitical alliances of late carbon capitalism displace and intensify the trauma of transition. What is worse, they risk undermining the necessarily global reach of decarbonization by encouraging - and rationally so - countries to avoid the new energy regimes. Unless energy transitions entail system transitions, and unless the systemic inequalities that produced these crises are rectified, any future 'after' the transition will look much like the unsurvivable present.

\section{References}

Acosta, A. 2000. El Ecuador post-petrolero. Quito: Acción Ecológica.

Al-Jazeera. 2019. US tells UN it is pulling out of Paris climate deal. Al-Jazeera November. Retrieved November 4, 2019 from https://www.aljazeera.com/news/2019/11/tells-quitting-paris-climateagreement-191104204531394.html

Aronoff, K., A. Battistoni, D. Cohen and T. Riofrancos. 2019. A planet to win: why we need a Green New Deal. London: Verso.

Arsel, M., B., Hogenboom and L. Pellegrini. 2016. The extractive imperative in Latin America. The Extractive Industries and Society 3(4): 880-887. 
Bakke, G. 2016. The electricity crisis in Venezuela: a cautionary tale. The New Yorker. Retrieved May 172019 from https://www.newyorker.com/tech/annals-of-technology/the-electricity-crisis-in-venezuela-acautionary-tale.

Baynard, C. 2011. The landscape infrastructure footprint of oil development: Venezuela's heavy oil belt. Ecological Indicators 11(3): 789-810.

Bernstein, S. and M. Hoffman. 2018. The politics of decarbonization and the catalytic impact of subnational climate experiments. Policy 51(2): 189-211.

Blackmore, L. 2017. Spectacular modernity: dictatorship, space, and visuality in Venezuela. Pittsburgh: University of Pittsburgh Press.

Bonilla, Y. and M. LeBrón (eds.). 2019. Aftershocks of disaster: Puerto Rico before and after the storm. Chicago: Haymarket Books.

Bonneuil, C. and J-B. Fressoz. 2016. The shock of the Anthropocene: the earth, history, and us. London: Verso.

Boyer, D. 2014. Energopower: an introduction. Anthropological Quarterly 87(2): 309-333.

Bradshaw, M.J. 2010. Global energy dilemmas: a geographical perspective. The Geographical Journal 176(4): $375-290$.

Brevini, B. and G. Murdock (eds.). 2017. Carbon capitalism and communication: confronting climate crisis. Cham: Springer.

Bridge, G. 2014. Energy (in)security: world-making in an age of scarcity. The Geographical Journal 181(4): 328-339.

Bridge, G., S. Bouzarovski, M. Bradshaw, and N. Eyre. 2013. Geographies of energy transition: space, place, and the low-carbon economy. Energy Policy 53: 331-340.

Brodzinksy, S. 2016. Venezuela declares two-day week in desperate attempt to save energy. The Guardian April 27, 2016. $\quad$ Retrieved $\quad$ February $\quad 11, \quad 2020 \quad$ from https://www.theguardian.com/world/2016/apr/27/venezuela-opposition-inches-forward-with-bid-toremove-nicolas-maduro

Buxton, J. 2016. Venezuela after Chávez. New Left Review 99(2): 5-25.

Carrington, D. 2019. 'Climate apartheid': UN expert says human rights may not survive. The Guardian June 25. Retrieved February 72020 from https://www.theguardian.com/environment/2019/jun/25/climateapartheid-united-nations-expert-says-human-rights-may-not-survive-crisis.

Cawthorne. A. 2016. Drought hit Venezuela awaits rain at crucial Guri dam. Reuters April 13, 2016 Retrieved February 11, 2020 fromhttps://www.reuters.com/article/us-venezuela-energy/drought-hitvenezuela-awaits-rain-at-crucial-guri-dam-idUSKCN0XA1WL

Cederlöf, G. 2017. Energy revolution: oil dependence and the political ecology of energy use in socialist Cuba. PhD dissertation. London, UK: King's College.

Cederlöf, G. and D. Kingsbury. 2019. On PetroCaribe: petropolitics, energopower, and post-neoliberal development in the Caribbean energy region. Political Geography 72: 124-133.

Chakrabarty, D. 2009. The climate of history: four theses. Critical Inquiry 35(2): 197-222.

Chancel, L. and T. Piketty. 2015. Carbon and inequality: from Kyoto to Paris trends in the global inequality of carbon emissions (1998-2013) and prospects for an equitable adaptation fund. Paris: Paris School of Economics.

Cohen, L. 2018. IMF sees Venezuela inflation at 10 million percent in 2019. Reuters Online October 9. Retrieved February 72020 from https://in.reuters.com/article/venezuela-economy/imf-sees-venezuelainflation-at-10-million-percent-in-2019-idINKCN1MJ1YX.

Coronil, F. 2011. The future in question: history and utopia in Latin America (1989-2010). In Calhoun, C. and G. Derlugian (eds.). Business as usual: the roots of the global financial meltdown. New York: New York University Press.

Coronil, F. 1997. The magical state: nature, money, and modernity in Venezuela. Chicago: University of Chicago Press.

D'Angelo, O. 2017. Sembrar el petróleo, por Arturo Ulsar Pietri (Caracas, 1906-2001). Retrieved February 7 2020 from https://digopalabratxt.com/2017/05/16/sembrar-el-petroleo-por-arturo-uslar-pietri-caracas1906-2001/. 
Davis, M. 2010. Who will build the Ark? New Left Review 61: 29-46.

Díaz-Briquets, S. and J.F. Pérez-López. 1995. The Special Period and the environment. Annals of the Association for the Study of the Cuban Economy 5.

DiMuzio, T. 2015. Carbon capitalism: energy, social reproduction and world order. New York: Rowman \& Littlefield.

Duany, J. 2017. Cuban migration: a postrevolution exodus ebbs and flows. Migration Policy Institute July 6. Retrieved February 72020 from https:/www.migrationpolicy.org/article/cuban-migrationpostrevolution-exodus-ebbs-and-flows.

Dupuy, A. 2010. Disaster capitalism to the rescue: the international community and Haiti after the earthquake. NACLA Report on the Americas 43(4): 14-19.

Dutch Risk Response Team. 2018. DRR Team Mission Report: Cuba - Havana Province and City. The Netherlands: DRR Team. Retrieved February 72020 from https://www.drrteam-dsswater.nl/wpcontent/uploads/2018/11/Report-DRR-Mission-Cuba-final-20181011.pdf.

Economic Commission for Latin America and the Caribbean (ECLAC). 2015. The economics of climate change in Latin America and the Caribbean: paradoxes and challenges of sustainable development. Santiago: United Nations.

Ellner, S. 2007. Toward a 'multipolar world': using oil diplomacy to sever Venezuela's dependence. NACLA Report on the Americas 40(5): 15-22.

Ellner, S., and M. Tinker Salas (eds.). 2006. Venezuela: Hugo Chávez and the decline of an "exceptional democracy." New York: Rowman \& Littlefield.

Energy Transitions Commission. 2016. Shaping energy transitions. London: Energy Transitions Commission. $\begin{array}{lllll}\text { Retrieved } & \text { February } & 7 & 2020 & \text { from }\end{array}$ transitions.org/sites/default/files/20160426\%20ETC\%20Position\%20Paper\%20vF\%20low-res.pdf.

Escobar, A. 2010. Latin America at a crossroads: alternative modernities, post-liberalism, or post-development? Cultural Studies 24(1): 1-65.

Fabricant, N. and B. Gustafson. 2017. Revolutionary oil? Offshore drilling in Cuba. NACLA Report on the Americas 49(4): 441-443.

Fernández, M., J. Williams, G. Figueroa, G. Graddy Lovelace, M. Machado, L. Vásquez, N. Pérez, L. Casimiro, G. Romero, and F. Funes Aguilar. 2018. New opportunities, new challenges: harnessing Cuba's advances in agroecology and sustainable agriculture in the context of changing relations with the United States. Elementa 6(1): 76.

Geels, F. 2014. Regime resistance against low-carbon transitions: introducing politics and power into the multilevel perspective. Theory, Culture, \& Society 31: 21-40.

Generation Energy Council. 2018. Canada's energy transition: getting to know our energy future, together. Ottawa: The Generation Energy Council. Retrieved February $7 \quad 2020$ from https://www.nrcan.gc.ca/sites/www.nrcan.gc.ca/files/energy/CoucilReport_june27_English_Web.pdf.

Gobierno del Estado Bolivariano de Yaracuy. 2018. Maduro anunció creación de la Industria Nacional de Agua.

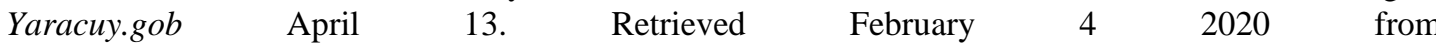
https://yaracuy.gob.ve/web/noticias/more/17802-Maduro-anunci-creacin-de-la-Industria-Nacional-delAgua

Goldthau, A. and J.M. Witte. 2010. The role of rules and institutions in global energy: an introduction. In Goldthau, A. and J.M. Witte (eds.). Global energy governance: the new rules of the game. Washington DC: Brookings Institute Press. Pp. 1-24.

Granma: Official Voice of the Communist Party of Cuba Central Committee. 2019. Consitución de la República de Cuba. Havana, Cuba: Granma. Retrieved February $7 \quad 2020$ from http://www.granma.cu/file/pdf/gaceta/Nueva\%20Constituci\%C3\%B3n\%20240\%20KB-1.pdf.

Grisanti, A. 2011. Venezuela's oil tale. Americas Quarterly 2(5): 39-42.

Gudynas, E. 2015. Extractivismos: ecología, economía y política de un modo de entender el desarrollo y la naturaleza. Cochabamba: Centro de Documentación e Información Bolivia. 
Guzmán, S. 2014. The role of Latin America in global emissions. Energy Transition: The Global Energiewende Blog, December 4. Retrieved February 72020 from https://energytransition.org/2014/12/the-role-oflatin-america-in-global-emissions/.

Hansen, J., P. Kharecha, M. Sato, V. Masson-Delmotte, F. Ackerman, D. J. Beerling, P. J. Hearty, O. HoeghGuldberg, S. Hsu, C. Parmesan, J. Rockstrom, E.J. Rohling, J. Sachs, P. Smith, K. Steffen, L. Van Susteren, K. von Schuckmann and J.C. Zachos. 2013. Assessing "dangerous climate change": required reduction of carbon emissions to protect young people, future generations and nature. Plos One 8(12): $1-26$.

Hardt, M. and A. Negri. 2000. Empire. Cambridge: Havard University Press.

Harnecker, C.P. 2014. Nonstate enterprises in Cuba: building socialism? Latin America Perspectives 41(4): 113-128.

Heffron, R.J. and D. McCauley. 2018. What is the 'just transition'? Geoforum 88: 74-77.

Hirschfeld Davis, J. 2017. Moving to scuttle Obama legacy, Donald Trump to crack down on Cuba. The New York Times, June 15. Retrieved February $7 \quad 2020$ from https://www.nytimes.com/2017/06/15/us/politics/cuba-trump-obama.html

Hodal, K. 2019. UN urged to declare full-scale crisis in Venezuela as health system 'collapses'. The Guardian April 5. Retrieved February 72020 from https://www.theguardian.com/globaldevelopment/2019/apr/05/un-urged-to-declare-full-scale-crisis-in-venezuela-as-health-systemcollapses

Hornborg, A., C. Cederlöf and A. Roos. 2019. Has Cuba exposed the myth of 'free' solar power? Energy, space, and justice. Environment and Planning E: Nature and Space 2(4): 989-1008.

Huber, M. 2015. Theorizing energy geographies. Geography Compass 9(6): 327-338.

Human Rights Watch. 2019. Venezuela's humanitarian emergency: large-scale UN response needed to address health and food crisis. New York: Human Rights Watch, April 4. Retrieved February 72020 from https://www.hrw.org/report/2019/04/04/venezuelas-humanitarian-emergency/large-scale-un-responseneeded-address-health

Institute of the Americas. 2015. Beyond Paris: energy transition in Latin America and the Caribbean. La Jolla: Institute of the Americas. Retrieved August $10 \quad 2015$ from https://www.iamericas.org/documents/energy/reports/Beyond_Paris.pdf.

International Crisis Group. 2004. Venezuela: headed toward civil war? Quito/Brussels: International Crisis Group. Retrieved February 72020 from https://d2071andvip0wj.cloudfront.net/venezuela-headedtoward-civil-war.pdf

Intergovernmental Panel on Climate Change (IPCC). 2014. Summary for policymakers. In Edenhofer, O., R. Pichs-Madruga, Y. Sokona, E. Farahani, S. Kadner, K. Seyboth, A. Adler, I. Baum, S. Brunner, P. Eickemeier, B. Kriemann, J. Savolainen, S. Schlömer, C. von Stechow, T. Zwickel and J.C. Minx (eds.). Climate change 2014: mitigation of climate change. Contribution of Working Group III to the Fifth assessment report of the Intergovernmental Panel on Climate Change. Cambridge and New York: Cambridge University Press.

Irazábal, C. and A. Punja. 2016. Cultivating just planning and legal institutions: a critical assessment of the South Central Farm struggle in Los Angeles. Journal of Urban Affairs 31(1): 1-23.

Kapcia, A. 2008. Cuba in revolution: a history since the fifties. London: Reacktion Books.

Karl, T.L. 1999. The perils of the petro-state: reflections on the paradox of plenty. Journal of International Affairs 53(1): 31-48.

Kestler-D'Amours, J. 2016. PM Trudeau green lights controversial oil pipeline. Al Jazeera Online, November 30. Retrieved February 72020 from https://www.aljazeera.com/news/2016/11/canada-greenlightscontroversial-oil-pipelines-161130113258928.html

Kingsbury, D. 2016. Oil's colonial residues: geopolitics, identity, and resistance in Venezuela. Bulletin of Latin American Research 35(4): 423-436.

Kingsbury, D., T. Kramarz and K. Jacques. 2018. Populism or petrostate?: The afterlives of Ecuador's YasuníITT Initiative. Society and Natural Resources 32(5): 530-547.

Klein, N. 2019. On fire: the (burning) case for a Green New Deal. New York: Simon \& Schuster. 
Knuth, S.E. 2015. Global finance and the land grab: mapping twenty-first century strategies. Canadian Journal of Development Studies/Revue canadienne d'études du développement 36(2): 163-178.

Kurmanaev, A. 2019. Venezuela's collapse is the worst outside of war in decades, economists say. The New York Times May 17. Retrieved February 7 2020 from https://www.nytimes.com/2019/05/17/world/americas/venezuela-economy.html

Lander, L.E. 1996. Insurrección de la tecnocracia petrolera en Venezuela. In H. Ochoa Henríquez and A.M. Estévez (eds.). El poder de los expertos: para comprender la tecnocracia. Maracaibo: Centro de Estudios de la Empresa, Facultad de Ciencias Económicas y Sociales.

Lander, L.E. 2007.Venezuela's balancing act: big oil, OPEC and national development. NACLA Report on the Americas 34(4): 25-31.

$\mathrm{Li}, \mathrm{X}$. and Y. Zhou. 2017. Offshoring pollution while offshoring production?. Strategic Management Journal 38(11): 2310-2329.

Lozano D. 2018. La crisis de la Venezuela chavista supera a Cuba en su peor emergencia: el Periodo Especial. El Mundo May 21. Retrieved February 7, 2020 from https://www.elmundo.es/internacional/2018/05/21/5b01a319e5fdeaf2738b462b.html.

Maduro, N. Twitter Post. April 12, 2018, 7:25PM. Retrieved February 42020 from https://twitter.com/NicolasMaduro/status/984573297311584256

Maal-Bared, R. 2006. Comparing environmental issues in Cuba before and after the Special Period: balancing sustainable development and survival. Environmental International 32: 349-358.

Malm, A. 2016. Fossil capital: the rise of steam power and the roots of global warming. London: Verso.

Mann, G. and J. Wainwright. 2018. Climate leviathan: a political theory of our planetary future. London: Verso.

Marsh, S. 2017. Cuba seeks to revive mining sector with new lead and zinc mine. Reuters Online July 22. Retrieved February 72020 from https://www.reuters.com/article/us-cuba-mining/cuba-seeks-to-revivemining-sector-with-new-lead-and-zinc-mine-idUSKBN1A70K3.

Martinez Alier, J. 2009. Socially sustainable economic de-growth. Development and Change 40(6): 1099-1119.

Maya, M.L. 2014. Venezuela: the political crisis of post-Chavismo. Social Justice 40(4): 68-87.

McNeill, J. and P. Engelke. 2016. The great acceleration: an environmental history of the Anthropocene since 1945. Cambridge, MA: Belknap Press.

Miller, C. and J. Richter. 2014. Social planning for energy transitions. Current Sustainable/Renewable Energy Reports 1: 77-84.

Milman, O., D. Smith and D. Carrington. 2017. Donald Trump confirms US will quit the Paris climate agreement. The Guardian June 1st. Retrieved February 72020 from https:/www.theguardian.com/environment/2017/jun/01/donald-trump-confirms-us-will-quit-parisclimate-deal

Mitchell, T. 2013. Carbon democracy: political power in the age of oil. London: Verso.

Monaldi, F. 2018. La implosión de la industria petrolera venezolana. ProDavinci August 15. Retrieved 25 November 2019 from https://prodavinci.com/la-implosion-de-la-industria-petrolera-venezolana/

Moore, J.W. 2015. Capitalism in the web of life: ecology and the accumulation of capital. London: Verso.

Morris, E. 2014. Unexpected Cuba. New Left Review 88: 5-45.

Newell, P. and D. Mulvaney. 2013. The political economy of the 'just transition'. The Geographical Journal 179(2): 132-140.

OPEC. 2019. Venezuela facts and figures. Retrieved November 272019 from https://www.opec.org/opec_web/en/about_us/171.htm

Pérez Cabrera, F. 2019. Tarea Vida señala el camino frente al cambio climático. Granma: Órgano oficial del Comité central del partido comunista de Cuba June 4. Retrieved February 72020 from http://www.granma.cu/cuba/2019-06-04/tarea-vida-senala-el-camino-frente-al-cambio-climatico-0406-2019-20-06-01.

Pérez, L. 2015. Cuba: between reform and revolution. Cambridge: Cambridge University Press.

Petrocultures Research Group. 2016. After oil. Edmonton: Petrocultures Research Group.

Pettifor, A. 2019. The case for a Green New Deal. London: Verso. 
Pineo, R. and L. Birns. 2013. Latin America's backyard. Council on Hemispheric Affairs August 23, 2013. Retrieved February 72020 from http://www.coha.org/latin-americas-backyard/.

Premat, A. 2003. Small-scale urban agriculture in Havana and the reproduction of the 'new man' in contemporary Cuba. Revista Europea de Estudios Latinoamericanos y del Caribe 75: 85-99.

Riofrancos, T. 2017. Extractivismo unearthed: a genealogy of a radical discourse. Cultural Studies 31(2-3): 277-306.

Roberts, D. 2016. Obama lands in Cuba as first US president to visit in nearly a century. The Guardian, March 21. Retrieved December 102019 from https://www.theguardian.com/world/2016/mar/20/barackobama-cuba-visit-us-politics-shift-public-opinion-diplomacy

Rodríguez-Labajos, B. 2019. Not so natural an alliance? Degrowth and environmental justice movements in the Global South. Ecological Economics 157: 175-184.

Romano, Silvina y Arantxa Tirado. 2018. Trump, el 'influencer' de la derecha latinoamericana. Centro Estratético Latinoamericano de Geopolítica October 28. Retrieved December 12019 from https://www.celag.org/trump-influencer-derecha-latinoamericana/

Rousseau, I. 2015. The dynamic of Latin American national oil companies' evolution case studies: Pemex and PdVSA. In Belyi, A.V. and K. Talus (eds.). States and markets in hydrocarbon sectors. London: Palgrave Macmillan.

Sachs, J. 2015. The age of sustainable development. New York: Columbia University Press.

Salas, M.T. 2009. The enduring legacy: oil, culture, and society in Venezuela. Durham: Duke University Press.

Sandberg, M., K. Klockars and K. Wilén. 2019. Green growth or regrowth? Assessing the normative justifications for environmental sustainability and economics growth through critical social theory. Journal of Cleaner Production 206: 133-141.

Shear, M.D. 2017. Trump Will Withdraw U.S. From Paris Climate Agreement. The New York Times June 1. Retrieved February 7, 2020 from https://www.nytimes.com/2017/06/01/climate/trump-paris-climateagreement.html

Smilde, D. 2019. Is an oil-for-food program plausible for Venezuela? Venezuela Blog March 21. Retrieved February 72020 from https://venezuelablog.org/oil-food-program-plausible-venezuela/.

Smil, V. 2016. Energy transitions: global and national perspectives. Santa Barbara: Praeger.

Stern, N. 2007. The economics of climate change: the Stern review. Cambridge: Cambridge University Press.

Stone, R. 2018. Cuba embarks on a 100-year plan to protect itself from climate change. Science Mag of the American Association for the Advancement of Science, January 10. Retrieved November 292019 from https://www.sciencemag.org/news/2018/01/cuba-embarks-100-year-plan-protect-itself-climate-change.

Svampa, M. 2017. Del cambio de época al fin de ciclo: gobiernos progresistas, extractivismo, y movimientos sociales en América Latina. Buenos Aires: Edhasa.

Swyngedouw, E. 2010. Apocalypse forever? post-political populism and the spectre of climate change. Theory, Culture, \& Society 27(2): 213-232.

Szeman, I. 2019. On petrocultures: globalization, culture, and energy. Morgantown: West Virginia University Press.

Tasker, J.P. 2019. Trudeau cabinet approves Trans Mountain expansion project. CBC News June 18. Retrieved February 72020 from https://www.cbc.ca/news/politics/tasker-trans-mountain-trudeau-cabinetdecision-1.5180269

Téran-Mantovani, E. 2014. El fantasma de la Gran Venezuela: un estudio del mito y los dilemas del petroestado en la revolución bolivariana. Caracas: Centro de Estudios Latinoamericanos Rómulo Gallegos.

TeleSur. 2018. Venezuela inaugura planta desalinizadora más grande de América Latina. TeleSur Net April 12. Retrieved February 72020 from https://www.telesurtv.net/news/inauguran-venezuela-plantadesalinizadora-mas-grande-20180412-0044.html

TeleSur. 2019. Relaciones Cuba-EE.UU. viven franco retroceso con Trump. TeleSur Net July 20. Retrieved February 72020 from https://www.telesurtv.net/news/cuba-eeuu-relaciones-diplomaticas-retrocesogobierno-donald-trump-20190720-0006.html

Tovar, M. 2019. Venezuela sufre el "Periódo Especial" del chavismo. EL Estímul April 5. Retrieved February 72020 from http://elestimulo.com/blog/venezuela-sufre-el-Periodo-eSpecial-del-chavismo/. 
The Economist. 2017. A battle for supremacy in the lithium triangle. The Economist June 15. Retrieved February 72020 from_https:/www.economist.com/the-americas/2017/06/15/a-battle-for-supremacy-in-thelithium-triangle.

Últimas Noticias. 2018. Presidente Maduro inauguro planta desalinizadora la península macanao. Retrieved November 2019 from http://www.ultimasnoticias.com.ve/noticias/economia/presidente-maduroinauguro-planta-desalinizadora-la-peninsula-macanao/.

UNFCC. 2014. Climate change threatens national security says Pentagon. Retrieved July 22019 from https://unfccc.int/news/climate-change-threatens-national-security-says-pentagon.

UNFCC. 2016. Climate change is biggest threat to global economy. Retrieved July 22019 from https://unfccc.int/news/climate-change-is-biggest-threat-to-global-economy.

UNHCR. 2019a. Refugees and migrants from Venezuela top 4 million: UNHCR and IOM. Retrieved June 15 2019 from_https://www.unhcr.org/news/press/2019/6/5cfa2a4a4/refugees-migrants-venezuela-top-4million-unhcr-iom.html.

UNHCR. 2019b. UN Human Rights report on Venezuela urges immediate measures to halt and remedy grave

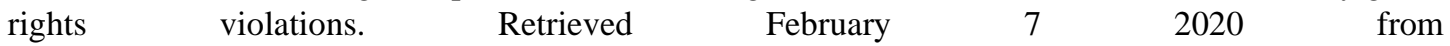
https://www.ohchr.org/EN/NewsEvents/Pages/DisplayNews.aspx?NewsID=24788\&LangID=E

UNGA. 2018. United Nations General Assembly, Seventy-third Session, Supplement No. 12. Part II: global compact on refugees. Report of the United Nations High Commissioner for Refugees, A/73/12. New York: United Nations.

Urry, J. 2013. Carbon capitalism and the problem of energy. Journal of Globalization Studies 4(1): 78-83.

Vázquez, G.E. 2015. 25 Years of contemporary history of PDVSA. In Bagley, B.M., H.S. Kassab and S. Moulioukova (eds.). The impact of emerging economies on global energy and the environment: challenges ahead. London: Lexington Books.

Verbong, G. and D. Loorbach. 2012. Introduction. In Verbong, G. and D. Loorbach (eds.). Governing the energy transition: reality, illusion, or necessity? New York: Routledge.

Watts, M.J. 2004. Resource curse? Governmentality, oil, and power in the Niger Delta, Nigeria. Geopolitics 9(1): 50-80.

Weisbrot, M. and J. Sachs. 2019. Economic sanctions as collective punishment: the case of Venezuela. Washington, D.C.: Center for Economic and Policy Research.

Wilpert, G. 2007. Changing Venezuela by taking power: the history and policies of the Chávez government. London: Verso.

Wright, J. 2009. Sustainable agriculture and food security in an era of oil scarcity: lessons from Cuba. New York: Routledge. 